\title{
CHANGES IN THE VALUES OF TWO ULTRASOUND- EXAMINED TEAT PARAMETERS DURING THE DRY PERIOD IN DAIRY COWS
}

\author{
Tamás TóтH ${ }^{1 *}$, Zsolt AвONYI-TóTH ${ }^{2}$, Ferenc PAJOR ${ }^{1}$, Róbert Kocsis ${ }^{3}$, \\ Alexandra JUHÁsz ${ }^{4}$, János TŐZsÉR ${ }^{1}$ and Péter PÓTI ${ }^{1}$ \\ ${ }^{1}$ Animal Husbandry Institute, Szent István University, Páter K. u. 1, H-2100 Gödöllő, \\ Hungary; ${ }^{2}$ Department of Biomathematics and Informatics, University of Veterinary \\ Medicine, Budapest, Hungary; ${ }^{3}$ Hungarian Milk Experimentation Institute, \\ Mosonmagyaróvár, Hungary; ${ }^{4}$ Department of Parasitology and Zoology, \\ University of Veterinary Medicine, Budapest, Hungary
}

(Received 7 July 2019; accepted 31 July 2019)

\begin{abstract}
The length of the streak canal and the area of the teat end were studied by ultrasound during the dry period in 40 Holstein-Friesian cows. In the first week, the values of these teat parameters decreased significantly $(\mathrm{P}<0.05)$ and this did not change significantly until the middle of the dry period. In the last month of gestation, the length of the streak canal was significantly reduced $(\mathrm{P}<0.05)$, while the area of the teat end did not decrease significantly $(P>0.05)$. At each of the five examination times, a very strong positive correlation $(r=0.85-0.94)$ was found between the two teat parameters. In healthy cows, the streak canal and the area of teat end, both of which are part of the udder's defence system, can regenerate sufficiently during the dry period, minimising the risk of contamination through the streak canal and the development of mastitis. If the regeneration of this defence system fails, the chances of infection through the streak canal increase.
\end{abstract}

Key words: Streak canal, area of teat end, ultrasound, cow, dry period

The economic efficiency of hygienic milk production depends largely on the health of the udder. Both mastitis and teat stenosis (Dinç et al., 2000) have an effect on milk production. The most common pathogens go through the open streak canal to the udder. The defence system of the teat is based on the blocking effect provided by the keratin plug in the streak canal and the closing muscles at the end of the teat. In order to prevent the udder from being infected, it is important to understand how the anatomy of the teat is influenced by the animal's age (Celik et al., 2008), breed (Klein et al., 2005; Seker et al., 2009), lactation number (Szencziová et al., 2013), milk yield (Comalli et al., 1984) and by the quality of machine milking (Húth, 2004). The structure of the teat was examined initially by radiography (McDonald, 1968) and then by non-invasive ultrasound

*Corresponding author; E-mail: utetamas.79@gmail.com; Phone: 0036 (20) 509-4883 
(Caruolo and Mochrie, 1967; Franz and Floek, 2009). Several teat parameters were examined by ultrasound, e.g. the length and thickness of the streak canal (Húth, 2004; Fasulkov et al., 2014; Strapák et al., 2017), the thickness of the udder wall (Stádnik et al., 2010), the area of teat end (Húth, 2004), the diameter of the pars papillaris (Stojnovič and Alagič, 2012), and the thickness of the teat (Klein et al., 2005).

The risk of developing mastitis in the early and late stages of the dry period is high. The purpose of this study was to determine how the length of the streak canal and the area of the teat end, which are important parts of the defence system of the udder, change during the dry period. Previously, Comalli et al. (1984) examined the changes in size, length and area of the streak canal during the dry period by ultrasound. Their examinations were limited to the first 30 days of the dry period. In contrast, our study was designed to determine how the teat parameters change over the entire dry period.

\section{Materials and methods}

\section{Study area and design}

This study was conducted on a dairy cattle farm near Pápa. The average number of cows in the farm is 876 , the annual milk production is $8,969 \mathrm{~kg} / \mathrm{cow}$. The cows were milked twice a day in a $2 \times 24$-position milking parlour with a Westfalia-type milking machine (vacuum: $42 \mathrm{KPa}$, pulsation ratio: 60:40, pulsation rate: 62). Teat parameter size changes were measured on 40 Holstein-Friesian cows throughout the dry period. At each examination time, the changes of the two teat parameters were compared. The first measurement was performed one day before the dry period (on day 222 of gestation), the subsequent three measurements were carried out on gestation days 229,250 and 271, while the fifth measurement took place on the day after calving. The first and the last measurements were performed before the morning milking.

\section{Ultrasound examination}

For the ultrasound examinations a SonoScape A6 ultrasound machine and 5-7 MHz linear transducers were used. All four teats of the cows were examined using a so-called water-bath method, in which the teats were immersed one by one in a $200-\mathrm{ml}$ plastic cup filled with $35^{\circ} \mathrm{C}$ water and the transducer applied with ultrasonic gel was placed outside the wall of the plastic cups parallel to the longitudinal axis of the teats. By this method the two parameters of the teat, the length of the streak canal (the distance between the outer and the inner opening of the streak canal in mm; Fig. 1) and the area of teat end (the area from the height of the Furstenberg's rosette in distal direction till the teat end, in $\mathrm{cm}^{2} ;$ Fig. 2) were measured. 


\section{Data analysis}

Statistical analyses were carried out using SPSS 18.0. For each teat parameter the average values of the examined teats of cows were calculated. After the normality check, the results obtained at the five different measurement times of the dry period were compared to each other with paired $t$-test. Bonferroni correlation was used for multiple comparisons. The significance level was set at 0.05.

\section{Results}

Compared with the last milking before the dry period, the length of the streak canal decreased from $10.8 \mathrm{~mm}$ to $9.9 \mathrm{~mm}$ within a week, this was a significant decrease of $8.3 \%(\mathrm{P}=0.002)$ (Fig. 3). By gestation day 250 the length of the streak canal increased by $0.4 \mathrm{~mm}$, which was not statistically significant $(\mathrm{P}=$ 0.072) compared to gestation day 229 (Fig. 3). On gestation day 271 the direction of change of streak canal length was reversed, as by that time point the length of the streak canal had decreased significantly $(\mathrm{P}=0.012)$ by $5.8 \% \mathrm{com}$ pared to gestation day 250 . The values measured after calving showed a further non-significant decrease of $4.1 \%$ in the last week of pregnancy $(\mathrm{P}=0.092)$.

A study by Tóth et al. (2018) showed that the length of the streak canal increases significantly $(\mathrm{P}<0.05)$ during milk production as lactation progresses. This increase in length occurs during lactation as a result of twice-a-day milking. A significant $(\mathrm{P}=0.002)$ length reduction of $8.3 \%$ was observed in the first week of dry period. Subsequently, until the end of udder involution, up to the middle of the dry period, the length of the streak canal does not change significantly. The udder begins to prepare for the next lactation from the middle of the dry period (Hurley, 2010); from that time point the length of the streak canal starts to decrease again. Regarding the entire duration of the dry period, the length of the streak canal decreased significantly (by $13.9 \%, \mathrm{P}=0.0001$ ).

Within one week after the last milking, the area of the teat end decreased significantly $(\mathrm{P}=0.0001)$ by $14.6 \%$ (Fig. 4). Over the subsequent three weeks it increased by $6.2 \%$; however, this increase was not significant $(\mathrm{P}=0.103)$. Compared to the value measured on gestation day 250 , the area of the teat end decreased by $3.6 \%$ by gestation day 271 , which decrease was not significant $(\mathrm{P}=0.347)$ (Fig. 4). Subsequently, until the post-calving measurement, the area of the teat end decreased further by $3 \%$, which change was no significant either $(\mathrm{P}=0.419)$. The area of the teat end had decreased significantly, by $15.2 \%(\mathrm{P}=0.0001)$ by the time of gestation. Like the length of the streak canal, the area of the teat end significantly decreases in the first week of the dry period $(P=0.0001)$. Considering the entire duration of the dry period, the area of the teat end decreased by $15.2 \%$, but most of the area loss occurred during the first week of the dry period, when the area decreased by $14.6 \%$. 


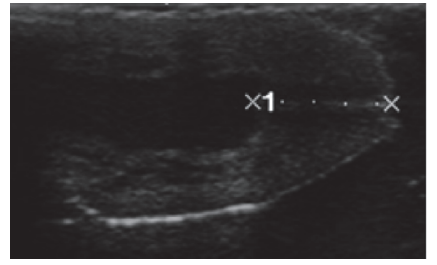

Fig. 1. The length of the teat canal which is the distance between the outer and the inner opening of the streak canal in $\mathrm{mm}$

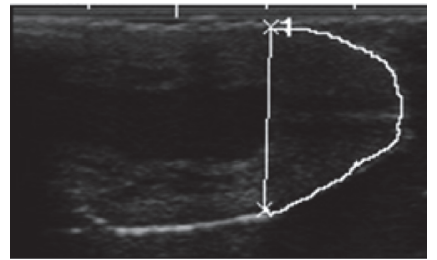

Fig. 2. The area of teat end which is the area from the height of the Furstenberg's rosette in distal direction till the teat end, in $\mathrm{cm}^{2}$

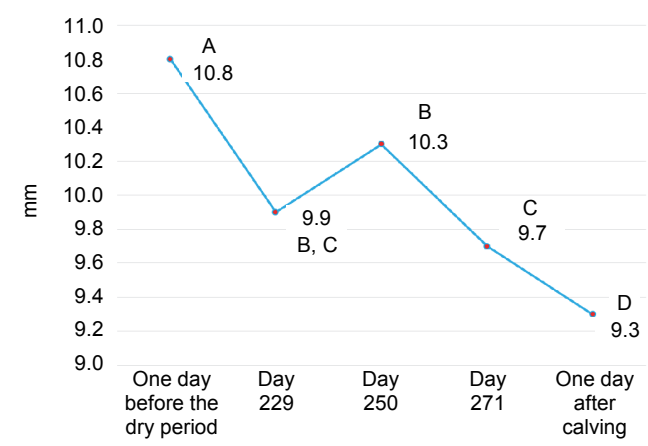

Fig. 3. The size change in length of the teat canal during the dry period. A, B, C are significantly different $(\mathrm{P}<0.05)$

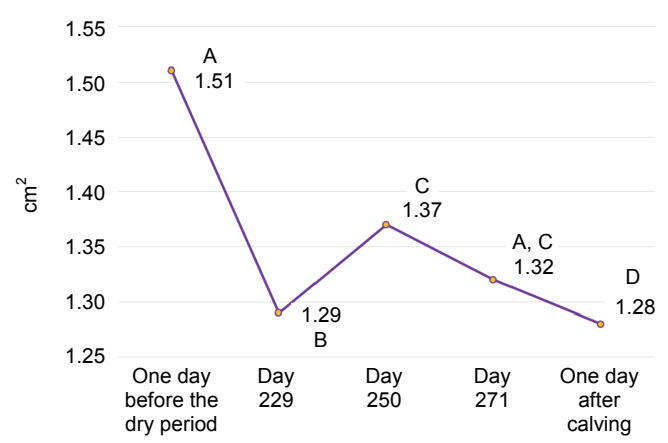

Fig. 4. Size change of the area of teat end during the dry period. A, B, C, D are significantly different $(\mathrm{P}<0.05)$ 
At each of the five examination times, a very strong correlation $(\mathrm{r}=0.85$ 0.94) was found between the length of the streak canal and the area of the teat end (Table 1).

Table 1

The correlation between the two teat parameters (length of the teat canal and area of the teat end) during the dry period

\begin{tabular}{cccccc}
\hline Teat parameters & $\begin{array}{c}\text { One day before } \\
\text { the dry period }\end{array}$ & Day 229 & Day 250 & Day 271 & $\begin{array}{c}\text { One day after } \\
\text { calving }\end{array}$ \\
\hline Correlation (r) & 0.89 & 0.9 & 0.87 & 0.85 & 0.94 \\
\hline
\end{tabular}

$\mathrm{P}<0.05$

\section{Discussion}

The results of ultrasound examination of the teat parameters in healthy cows shows that the length of the streak canal and the area of the teat end gradually increase $(\mathrm{P}<0.05)$ over time during lactation in a twice-a-day milking system (Tóth et al., 2018).

The chance of developing a new case of mastitis is the highest in the first 1-2 weeks of the dry period (Hurley, 2010). In the early stages of the dry period, the development of mastitis is facilitated by the fact that milk does not leave the lactiferous ducts when milking is lost, and its production is further increased in the first 2-4 days of the dry period, thus increasing the size of the udder's cavity system. Bacteria multiply rapidly in the accumulated milk. Due to the pressure of milk accumulated in the lactiferous ducts, milk leakage can be observed through the open streak canal at that stage of the dry period, which increases the possibility of infection.

The results of this study indicate that the teat parameters of healthy cows undergo significant changes during the first week of the dry period. In this study, the length of the streak canal decreased by $8.3 \%$ and the area of the teat end decreased by $14.6 \%$ in that period. These dimensional changes indicate that the streak canal and the area of the teat end which are components of the defence system of the teat, regenerate significantly during the first week of the dry period and thus minimise the possibility of contamination through the streak canal. This was confirmed by a previous study by Húth (2004), according to which the risk of developing mastitis increases with the length increase of the streak canal. Thus, in the first week of the dry period, the risk of infection through the streak canal increases significantly if the length of the streak canal does not decrease significantly $(\mathrm{P}<$ $0.05)$ during that period. Therefore, effective antibiotic therapy after the last milking prior to drying off is important for preventing the development of mastitis in the early period of udder involution. 
In the middle of the dry period (around day 25), the involution of the udder is completed (Capuco and Akers, 1999). At that stage of the dry period the risk of developing mastitis is minimised by the fact that the streak canal becomes closed and milk leakage is no longer observed. The amount of milk is significantly reduced in the udder system, and therefore the size of the cavity system decreases to $9.5 \%$ of the value measured in lactating cows. Macrophages remove the milk that accumulates in the lactiferous ducts, and the number of macrophages significantly increases in the udder tissues after the 7th day of the dry period (Hurley, 2010). The composition of the fluid present in the cavity system of the udder is less conducive to the growth of pathogens.

The length of the streak canal and the area of the teat end showed no significant size increases $(4 \%, \mathrm{P}=0.072$ and $6.2 \%, \mathrm{P}=0.103$, respectively) from the first week of the dry period to the end of udder involution. Thus, at that stage of udder involution, increased activity of the macrophages change the dimensions of the udder parameters only to a small extent and for a short time. Based on the results of this study, it can be concluded that in healthy cows the regeneration of these two teat parameters occurs in the early stages of involution.

In the final stages of the dry period, particularly when colostrum production begins, the risk of udder infestation increases once more (Hurley, 2010). This is caused by the production of colostrum in the udder, which increases the size of the lactiferous ducts. The periodic removal of the produced milk from the lactiferous ducts does not begin until calving. Also, as the pressure in the udder increases, milk flow through the streak canal starts.

In the final stage of the dry period, when the udder prepares for the next lactation, the length of the streak canal and the area of the teat end decrease further by $9.9 \%$ and $6.6 \%(\mathrm{P}=0.0001$ and $\mathrm{P}=0.038$, respectively). In healthy cows, the risk of infection through the streak canal and of the consequent development of mastitis are minimised at the end of the dry period by the fact that the length of the streak canal undergoes a further significant decrease $(\mathrm{P}<0.05)$.

Throughout the dry period, there was a very strong $(r=0.85-0.94)$ correlation between the length of the streak canal and the size change of the area of teat end, which confirms that these two teat parameters form a very tightly related unit in the udder defence system.

In conclusion, in healthy cows the streak canal and the area of the teat end can regenerate sufficiently during the dry period, thus minimising the risk of contamination through the streak canal and the development of mastitis. If regeneration of the defence system fails, the chances of infection through the streak canal increase. Regular ultrasound scanning of the teat parameters during the dry period enables the monitoring of udder involution. In addition, through the diagnosis of teat disorders before infection the development of mastitis can be prevented. 


\section{References}

Capuco, A. V. and Akers, R. M. (1999): Mammary involution in dairy animals. J. Mammary Gland Biol. Neoplasia 4, 137-144.

Caruolo, E. V. and Mochrie, R. D. (1967): Ultrasonograms of lactating mammary glands. J. Dairy Sci. 50, 225-230.

Celik, H. A., Aydin, I., Colak, M., Sendag, S. and Dinc, D. A. (2008): Ultrasonographic evaluation of age related influence on the teat canal and the effect of this influence on milk yield in Brown Swiss cows. Bull. Vet. Inst. Pulawy 52, 245-249.

Comalli, M. P., Eberhart, R. J., Griel, L. C. and Rothenbacher, H. (1984): Change in the microscopic anatomy of the bovine teat canal during mammary involution. Am. J. Vet. Res. 45, $2236-2242$.

Dinç, D. A., Şendağ, S. and Aydin, I. (2000): Diagnosis of teat stenosis in dairy cattle by real-time ultrasonography. Vet. Rec. 147, 270-272.

Fasulkov, I., Vasilev, N., Karadaev, M. and Dineva, G. (2014): Visualization and measurement of teat structures in black and white cows through ultrasonography. Mac. Vet. Rev. 37, 89-93.

Franz, S., Floek, M. and Hofmann-Parisot, M. (2009): Ultrasonography of the bovine udder and teat. Vet. Clin. North Am. Food Anim. 25, 669-685.

Hurley, W. L. (2010): Dry period and mastitis. Lactation Biology website. http://ansci.illinois.edu/ static/ansc438/index.html

Húth, B. (2004): Selection Options for Improvement of Machine Milking in the Hungarian Simmental Breed [in Hungarian]. Doctoral Dissertation, Kaposvár, Hungary.

Klein, D., Khol, J. L., Stüger, H. P. and Baumgartner, W. (2005): Ultrasonographic measurement of the bovine teat: breed differences, and the significance of the measurements for udder health. J. Dairy Res. 72, 296-302.

McDonald, J. S. (1968): Radiographic method for anatomic study of the teat canal: changes with lactation age. Am. J. Vet. Res. 29, 1207-1210.

Seker, I., Yuker, M., Saat, N. and Ozmen, O. (2009): Relationship between California Mastitis Test score and ultrasonographic teat measurements in dairy cows. Aust. Vet. J. 87, 480-483.

Stádnik, L., Louda, F., Bezdíček, J., Ježková, A. and Rákos, M. (2010): Changes in teat parameters caused by milking and their recovery to their initial size. Arch. Tierzucht 53, 650-662.

Stojnovič, M. and Alagič, D. (2012): Machine milking and dairy changes of cow's teat condition. Acta Agric. Slov. 3, 303-307.

Strapák, P., Strapáková, E., Rušinová, M. and Szencziová, I. (2017): The influence of milking on the teat canal of dairy cows determined by ultrasonographic measurements. Czech J. Anim. Sci. 62, 75-81.

Szencziová, I., Strapák, P., Stádnik, L., Ducháček, J. and Beran, J. (2013): Relationship of udder and teat morphology to milking characteristics and udder health determined by ultrasonographic examinations in dairy cows. Ann. Anim. Sci. 13, 783-795.

Tóth, T., Abonyi Tóth, Zs., Kocsis, R., Pajor, F., Póti, P. and Tőzsér, J. (2018): Size changes in some ultrasound examined teat parameters during milking in different lactation stages [in Hungarian, with English abstract]. Magyar Allatorvosok 140, 663-668.

This is an open-access article distributed under the terms of the Creative Commons Attribution 4.0 International License (https://creativecommons.org/licenses/by/4.0/), which permits unrestricted use, distribution, and reproduction in any medium, provided the original author and source are credited, a link to the CC License is provided, and changes - if any - are indicated. (SID_1) 